\title{
Melon yellow spot virus: A Distinct Species of the Genus Tospovirus Isolated from Melon
}

\author{
K. Kato, K. Hanada, and M. Kameya-Iwaki
}

First author: Shizuoka Agricultural Experiment Station, 678-1 Tomioka, Toyoda, Shizuoka, 438-0803, Japan; second author: Kyushu National Agricultural Experiment Station, 2421 Suya, Nishigoushi, Kikuchi, Kumamoto, 861-1192, Japan; third author: Faculty of Agriculture, Yamaguchi University, 1677-1 Yoshida, Yamaguchi, 753-8515, Japan. Accepted for publication 7 January 2000.

\begin{abstract}
Kato, K., Hanada, K., and Kameya-Iwaki, M. 2000. Melon yellow spot virus: A distinct species of the genus Tospovirus isolated from melon. Phytopathology 90:422-426.

A tospovirus-like virus recovered from netted melon was transmitted by Thrips palmi in a persistent manner but had different cytopathological features from tospoviruses previously reported. Viral nucleocapsid $(\mathrm{N})$ was purified with two protective reagents, 2-mercaptoethanol and Lascorbic acid, and RNA extracted from the viral nucleocapsid was used for genomic analysis. The virus had a genome consisting of three single-

mentary strand, located at the $3^{\prime}$ end of the viral S RNA, encoded the N protein. The $3^{\prime}$ terminus of this RNA also contained an eight-nucleotide sequence similar to the conserved sequence at the $3^{\prime}$ end of genomic RNA molecules of tospoviruses. These features of the viral genome are identical to those of tospoviruses; therefore, this virus is considered to belong to the genus Tospovirus. Its N protein comprised 279 amino acids and had a molecular mass of $31.0 \mathrm{kDa}$. Comparisons of its amino acid sequence with those of known tospoviruses revealed less than $60 \%$ identity. This melon virus is concluded to be a distinct species in the genus Tospovirus, and the name Melon yellow spot virus is proposed.
\end{abstract} stranded RNA molecules. The open reading frame on the viral comple-
Members of the genus Tospovirus of the family Bunyaviridae are transmitted by thrips in a persistent, propagative manner $(6,31)$. The genome structure of tospoviruses has been reviewed both by German et al. (6) and by Mumford et al. (23). Tospoviruses have quasispherical enveloped particles containing three linear singlestranded genomic RNAs, designated S, M, and L. Inverted complementary repeat sequences are found at the termini of these RNA molecules, and the sequence of the first eight $3^{\prime}$-terminal nucleotides (5'-AUUGCUCU-3') is conserved among the S, M, and L RNAs of all tospoviruses whose sequence data have been published. Complete genomic nucleotide sequencing of Tomato spotted wilt virus (TSWV) revealed that the $\mathrm{S}$ and $\mathrm{M}$ RNAs have an ambisense organization.

The S RNA has two open reading frames (ORFs) separated by an A-U-rich intergenic region. The larger ORF at the $5^{\prime}$ end of the viral-sense strand encodes a nonstructural protein (NSs). The smaller ORF on the viral complementary strand is located at the $3^{\prime}$ end of the viral RNA and encodes a nucleocapsid (N) protein. Tospoviruses are classified into several species, based on amino acid sequence identity of the $\mathrm{N}$ protein, host range, and vector specificity (7). Nucleotide sequences of the $\mathrm{N}$ genes of several tospoviruses have been determined $(1,3,5,14,19,28,29,33)$. Among tospoviruses, Watermelon silver mottle virus (WSMV), Watermelon bud necrosis virus (WBNV), and Zucchini lethal chlorosis virus (ZLCV) have been reported to systemically infect members of the family $\mathrm{Cu}$ curbitaceae $(4,13,14)$.

A tospovirus-like virus isolated from diseased netted melon $(\mathrm{Cu}$ cumis melo L.) plants showed persistent transmission by Thrips palmi (15). This virus had a unique host range and was not serologically related in enzyme-linked immunosorbent assay (ELISA)

Corresponding author: K. Kato;

E-mail address: byo004@ agri-exp.pref.shizuoka.jp

Publication no. P-2000-0216-01R

(C) 2000 The American Phytopathological Society tests to TSWV (17) and WSMV (13) previously reported in Japan. In addition, electron microscopy revealed that enveloped particles with an average diameter of $135 \mathrm{~nm}$ were abundantly scattered throughout the cytoplasm of infected cells.

In this article, further cytopathological features, genomic analysis of the $\mathrm{N}$ gene, and serological characterization of the melon virus are reported, indicating that this virus is a distinct species of the genus Tospovirus.

\section{MATERIALS AND METHODS}

Virus maintenance. The virus isolate originally obtained from netted melon (15) was maintained in cucumber ( $C$. sativus). Systemically infected cucumber leaves were stored at $-80^{\circ} \mathrm{C}$ and subsequently used as inocula. Other virus isolates used in this study were WSMV from Okinawa Prefecture (13) and TSWV from Nara Prefecture (17), both of which were maintained on Nicotiana rustica.

Electron microscopy. Tospoviruses become defective after repeated mechanical transmission (24); therefore, ultrathin sections were prepared from diseased leaves of cucumber infected via thrips according to the method described by Iwaki et al. (13).

Purification of nucleocapsid. The virus lost its sap-transmissibility very rapidly; therefore, 2-mercaptoethanol and L-ascorbic acid were selected as protective reagents by preliminary tests. Viral nucleocapsid was purified from systemically infected leaves of cucumber as described by Hanada et al. (8) for WSMV with some modifications. Phosphate buffer (0.1 M, pH 7.0) containing $20 \mathrm{mM}$ 2-mercaptoethanol and $15 \mathrm{mM}$ L-ascorbic acid was used for extracting and resuspending the nucleocapsid throughout the purification procedure. After 10 to $40 \%$ sucrose density-gradient centrifugation of the concentrated nucleocapsid, each gradient was fractionated into 12 fractions. The fractions containing the nucleocapsid were selected by detection of virus-specific nucleic-acid bands (8).

Analysis of the $\mathbf{N}$ protein. To determine the size of the viral $\mathrm{N}$ protein, sodium dodecyl sulfate-polyacrylamide gel electrophore- 
sis (SDS-PAGE) was performed (18). Nucleocapsid preparations were obtained from infected cucumber. Nucleocapsids of TSWV and WSMV also were prepared from infected leaves of $N$. rustica (8). Proteins in the nucleocapsid preparations were separated by $12 \%$ SDS-PAGE. Gels were stained with Coomassie brilliant blue. Proteins purified from both healthy cucumber and healthy N. rustica served as the control.

The western blot technique was used for analyzing serological relationships among the $\mathrm{N}$ proteins of the melon virus, TSWV, and WSMV. After separation by $12 \%$ SDS-PAGE, proteins in the nucleocapsid preparations were transferred to nitrocellulose membranes (Amersham Pharmacia Biotech, Ltd., Little Chalfont, England) using a semidry electroblotting system (Nippon Eido, Tokyo). Immunostaining of the membranes was carried out as described by Hibi and Saito (9). The antiserum to the melon virus $\mathrm{N}$ protein prepared previously (15) was used in a 1:400 dilution.

Sizes of genomic RNA segments. To determine the sizes of viral genomic RNA segments, electrophoresis in 1\% agarose gels containing formaldehyde was carried out (26) with RNA extracted from nucleocapsid preparations according to the method described by de Avila et al. (2). After electrophoresis, gels were stained with ethidium bromide.

Cloning and sequencing of the $\mathbf{N}$ gene. After disruption with $1 \%$ SDS, the viral nucleocapsid was electrophoresed in $1.3 \%$ lowmelting agarose gels. The $3^{\prime}$ end of the smallest RNA (S RNA) recovered from gels (25) was directly sequenced (15 nt) according to the method described by Hidaka et al. (10).

The viral S RNA recovered from $1.3 \%$ low-melting agarose gels was subjected to cDNA synthesis using the cDNA Synthesis System Plus (Amersham Pharmacia Biotech). The cDNA synthesis was primed with a degenerate primer (5'-AGAGC/TAATC/TAAGGTA-3') based on the 3'-end sequence information of the S RNA. Blunt-ended cDNA samples were cloned into EcoRV-digested pBluescript II SK ${ }^{+}$vector (Stratagene, La Jolla, CA). Obtained clones were screened using the ECL Gene Detection System (Amersham Pharmacia Biotech) with gel-purified S RNA as a probe. A positive clone, pMY1, was obtained. For further cloning, an additional primer (5'-GTAAACACCATGTCTACCGT-3') was designed based on the sequence information of pMY1, which anneals to nucleotides 59 to 78 from the $3^{\prime}$ end. Clone pMY2 was selected for further sequencing through screening.

Sequencing was done by the dideoxynucleotide chain termination method (27) with Dye primer cycle sequencing kit (Applied Biosystems Inc., Foster, CA). The nucleotide sequences were determined from both strands. The sequence data of the putative viral $\mathrm{N}$ gene was compared with those of other tospoviruses available from the DNA Data Bank of Japan (DDBJ) using GENETYXMAC software (Software Development Co., Tokyo).
Expression of the $\mathbf{N}$ gene in bacteria. Clone pMY2, containing complementary viral-strand DNA corresponding to the entire putative $\mathrm{N}$ gene of the melon virus, was selected for expression analysis in bacteria. An insert containing the entire putative $\mathrm{N}$ gene, obtained from digestion of pMY2 with BamHI and HincII, was ligated with an NcoI linker (5'-GCCATGGC-3'). After digestion with $N c o I$, an insert was subcloned into the pET-3D expression vector (Novagen, Madison, WI) predigested with BamHI and NcoI.

After transformation of the resulting clone into Escherichia coli strain BL21 (DE3) pLysS (Stratagene), protein expression was induced for $3 \mathrm{~h}$ at $37^{\circ} \mathrm{C}$ by adding isopropyl- $\beta$-D-thiogalactopyranoside at a final concentration of $0.5 \mathrm{mM}$. Protein extracts from lysed bacterial cells were subjected to $12 \%$ SDS-PAGE, and western blot was performed.

\section{RESULTS}

Electron microscopy. As we reported previously (15), enveloped particles were observed scattered throughout the cytoplasm in infected cells of cucumber (Fig. 1A). Particles appeared to be enveloped with double membranes (Fig. 1B). These double-enveloped particles (DEPs) were often associated with membranes (Fig. 1A). Clustering of single-enveloped virions (SEVs) within

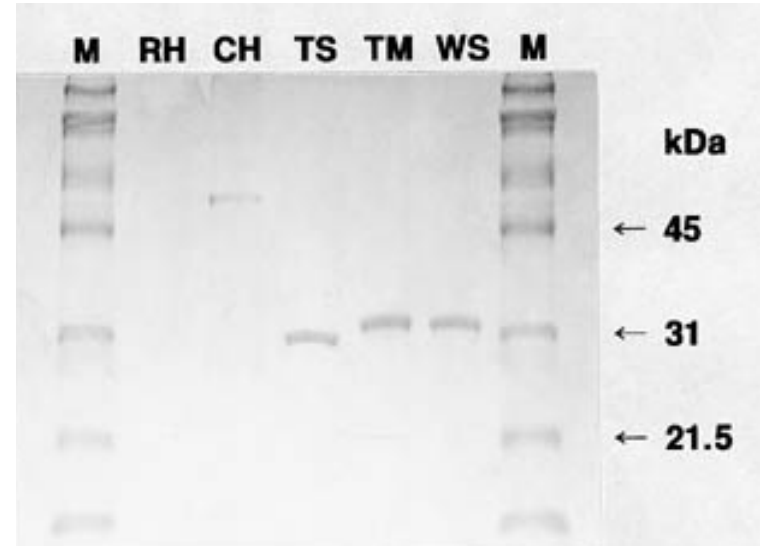

Fig. 2. Sodium dodecyl sulfate-polyacrylamide gel electrophoresis (SDS-PAGE) analysis of the Tomato spotted wilt virus (TSMV), Watermelon silver mottle virus (WSMV), and melon virus nucleocapsid proteins. Partially purified nucleocapsid preparations were subjected to $12 \%$ SDS-PAGE and proteins stained with Coomassie brilliant blue. Lane $\mathrm{RH}$, healthy Nicotania rustica; lane $\mathrm{CH}$, healthy cucumber; lane TS, nucleocapsid of TSWV; lane TM, nucleocapsid of melon virus; lane WS, nucleocapsid of WSMV. Lane M, protein molecular-weight markers (Bio-Rad Laboratories, Hercules, CA).
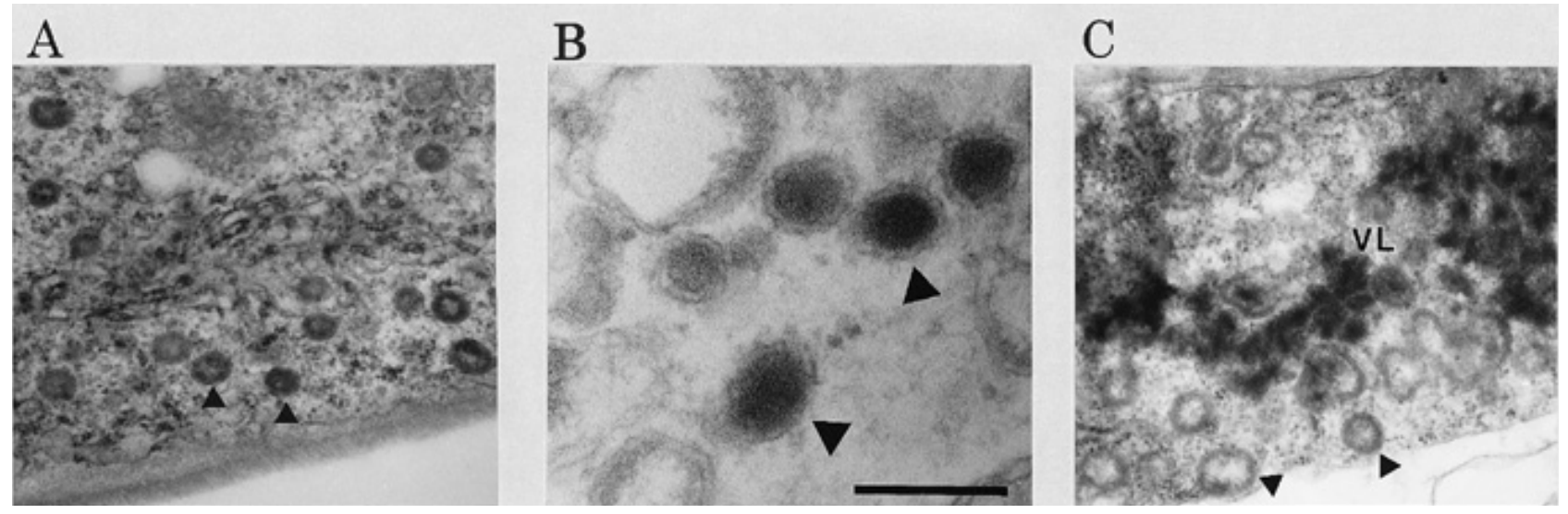

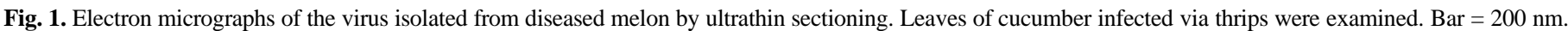

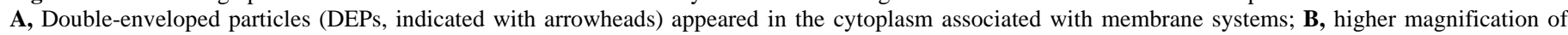

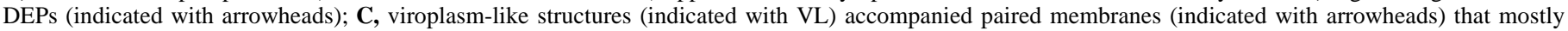
appeared as rings. 
the cisternae of endoplasmic reticulum (ER), characteristic of tospovirus infection $(11,16,21,22)$, was not observed. In addition to DEPs, viroplasm-like structures (VLSs) appeared in the cytoplasm of some infected cells accompanying prominent paired membranes (PMs) (Fig. 1C). These structures were fairly electron dense and some of them displayed a chain-like appearance. PMs varied in appearance and often appeared as rings of variable size and content (Fig. 1C).

Analysis of the $\mathbf{N}$ protein. A single protein almost the same size as the WSMV N protein was detected from the nucleocapsid preparation of the melon virus in SDS-PAGE (Fig. 2). There were no corresponding bands in the healthy control. This protein is considered to be the $\mathrm{N}$ protein, because it produces the band intensively stained in western blot with the antiserum to the melon virus $\mathrm{N}$ protein (Fig. 3). The molecular mass of the protein was estimated to be $31.9 \mathrm{kDa}$.

In western blots, the melon virus antiserum reacted weakly with the WSMV N protein as well, although a serological relationship between these two viruses was not found in ELISA tests (15). Thus, some common epitopes might exist in the $\mathrm{N}$ proteins of both viruses.

\section{RH CH TS TM WS}

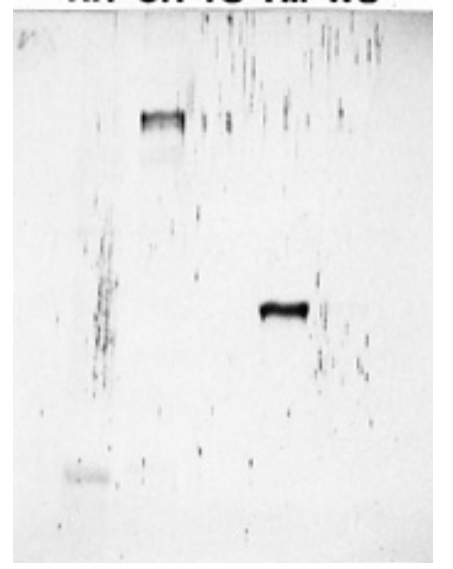

Fig. 3. Western blot analysis of the nucleocapsid $(\mathrm{N})$ proteins of Tomato spotted wilt virus (TSWV), Watermelon silver mottle virus (WSMV), and the melon virus with a polyclonal antiserum to the $\mathrm{N}$ protein of the melon virus. Lane $\mathrm{RH}$, healthy Nicotania rustica; lane $\mathrm{CH}$, healthy cucumber; lane TS, nucleocapsid of TSWV; lane TM, nucleocapsid of melon virus; lane WS, nucleocapsid of WSMV.

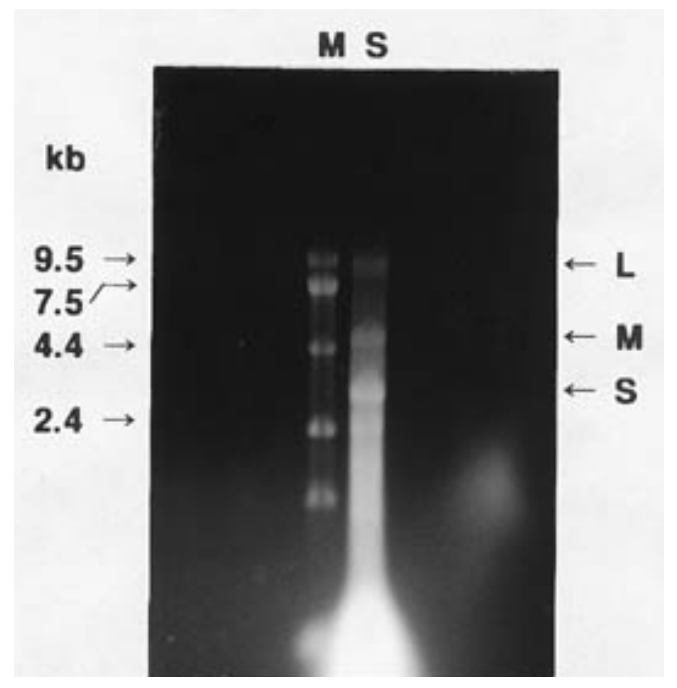

Fig. 4. Denaturing electrophoresis of virion RNAs extracted from the melon virus nucleocapsid protein (lane $\mathrm{S}$ ). Lane $\mathrm{M}$, single-stranded RNA markers (Life Technologies, Rockville, MD). To the right, S, M, and L indicate viral genomic RNA segments.
Sizes of genomic RNA segments. In agarose gel electrophoresis under denaturing conditions, three RNA segments were detected (indicated as L, M, and S in Figure 4). The sizes of these segments were estimated to be $9.1,4.9$, and $3.1 \mathrm{~kb}$, respectively.

Sequence analysis of the $\mathbf{N}$ gene. The clones pMY1 and pMY2 contained inserts of 124 and $851 \mathrm{bp}$, respectively. The sequence of 909 nt from the 3' end of the viral RNA was determined from these two clones. Nucleotide sequence analysis revealed that one ORF on the viral complementary strand started at nucleotide position 68 and terminated at nucleotide position 907 (numbered from the $3^{\prime}$ end of the viral RNA). This ORF encodes a $31.0-\mathrm{kDa}$ protein comprising 279 amino acids and is considered the $\mathrm{N}$ gene (DDBJ Accession no. AB024332). The predicted molecular mass of $31.0 \mathrm{kDa}$ fit well with the value of $31.9 \mathrm{kDa}$ determined by SDS-PAGE with the purified $\mathrm{N}$ protein.

Comparisons of the amino acid sequence of the putative $\mathrm{N}$ protein with those of the $\mathrm{N}$ proteins reported for known tospoviruses showed that it shared 58 to $60 \%$ identity with the $\mathrm{N}$ proteins of three tospoviruses in serogroup IV: Peanut bud necrosis virus (PBNV), WSMV, and WBNV (Table 1). However, identities with the $\mathrm{N}$ proteins of six other tospoviruses were less than $50 \%$.

A multiple alignment for the $\mathrm{N}$ protein amino acid sequences of the melon virus and three tospoviruses in serogroup IV revealed the presence of several conserved regions (Fig. 5), whereas very little conservation was found when all known $\mathrm{N}$ protein amino acid sequences were aligned (data not shown). Possibly, some of the conserved regions are common epitopes, considering that the melon virus $\mathrm{N}$ protein is serologically related to that of WSMV.

Expression of the $\mathbf{N}$ gene in bacteria. In western blot, the melon virus $\mathrm{N}$ protein-specific antiserum reacted with a protein with an estimated molecular mass of $33.0 \mathrm{kDa}$ present in the protein extract from bacterial cells in which the expression of the putative melon virus $\mathrm{N}$ gene was induced (Fig. 6). The estimated molecular mass of $33.0 \mathrm{kDa}$ agreed with the expected size of the expression product $(32.3 \mathrm{kDa})$. As expected, the molecular mass of this protein was slightly larger than that of the purified $\mathrm{N}$ protein due to the addition of 11 amino acids derived from the vector. These results clearly indicate that the ORF identified on the viral complementary strand encodes the $\mathrm{N}$ protein.

\section{DISCUSSION}

Tospovirus infection in plant cells is typically characterized by the presence of SEVs clustered within the membranous cisternae, double-enveloped virions (DEVs), nucleocapsid aggregates (NCAs), paired parallel membranes (PPMs), and accumulation of NSs protein $(11,16,20-22)$. From time-course studies with TSWV, Milne (22) reported that DEVs, PPMs, and viroplasms (considered NCAs) were associated with an early stage of infection, and only SEVs were observed in a late stage (22). DEVs are considered to be immature virions of tospoviruses and to fuse with the ER mem-

TABLE 1. Comparison of the amino acid sequence of the melon virus nucleocapsid $(\mathrm{N})$ protein with those of the $\mathrm{N}$ proteins reported for tospoviruses

\begin{tabular}{lcc}
\hline Virus $^{\mathrm{a}}$ & \multicolumn{2}{c}{$\begin{array}{c}\text { Amino acid sequence } \\
\text { identity }(\%)^{\mathrm{b}}\end{array}$} \\
\hline Tomato spotted wilt virus (D13926) & I & 29 \\
Tomato chlorotic spot virus (S54325) & II & 30 \\
Groundnut ringspot virus (S54327) & II & 29 \\
Impatiens necrotic spot virus (D00914) & III & 28 \\
Peanut bud necrosis virus (U27809) & IV & 60 \\
Watermelon silver mottle virus (X78556) & IV & 58 \\
Watermelon bud necrosis virus (AF045067) & IV & 59 \\
Peanut yellow spot virus (AF013994) & V & 25 \\
Iris yellow spot virus (AF001387) & VI & 49
\end{tabular}

a The sequences used in comparisons were obtained from the DNA Data Bank of Japan. Accession numbers are given in parentheses.

b Identities were calculated using GENETYX-MAC software. 
brane, releasing mature SEVs in the cisternae (16,22). Typically, NCAs have been reported to show a chain-like configuration and striations and to be electron dense $(11,16,20)$. PPMs associated with virion formation appear as straight, curved, ring-, or horseshoeshaped structures $(16,20,22)$. The accumulation of NSs protein differs in appearance, depending on the species of tospovirus, the stage of infection, and the host $(6,16,20)$. Several isolates of tospoviruses are morphologically defective $(12,21,24)$. Among them, the HT-2 isolate of Impatiens necrotic spot virus was reported to produce numerous DEVs with SEVs (21).

Infection with the melon virus typically induced PMs, VLSs, and DEPs in the cytoplasm of cells. PMs, mostly appearing as rings, were quite similar to PPMs induced by tospovirus infection. VLSs observed associated with PMs possessed the features of tospovirus NCAs, except for visible striations. In addition, DEPs abundantly observed in infected cells resembled DEVs of tospoviruses. However, we do not consider DEPs to be immature virions nor this virus to be morphologically defective. Despite time-consuming efforts to examine infected cells in various infection stages, including a late stage, only DEPs were found, suggesting that DEPs are not immature virions. Moreover, the samples of infected plants used for electron microscopy were prepared by thrips transmission. The virus is capable of thrips transmission and a complete infection cycle; therefore, we suggest that the virus is not defective and that DEPs are virions. However, immunoelectron microscopic studies are necessary to demonstrate that DEPs, in fact, are virions.

The melon virus was transmitted by the same mode as tospoviruses (15) but induced virion-like particles with double envelopes scattered throughout the cytoplasm of infected cells. Nevertheless, we considered that this virus might belong to the genus Tospovirus due to its unique transmission via thrips. To establish its taxonomic position, genomic analysis was performed. This virus had a genome consisting of three ssRNA molecules of $\approx 9.1,4.9$, and $3.1 \mathrm{~kb}$, respectively. These sizes agree with those of the L, M, and S RNAs reported for tospoviruses $(6,23,28,30,32)$. Direct RNA sequencing revealed that the $3^{\prime}$-terminal nucleotide sequence of the S RNA ( $5^{\prime}$-AUUG/ACUCU-3') is similar to the conserved sequence of genomic RNA molecules of tospoviruses (5'-AUUGCUCU-3'). The ORF on the viral complementary strand, located at the $3^{\prime}$ end of the viral S RNA, was confirmed to encode the $\mathrm{N}$ protein with a molecular mass of $31.0 \mathrm{kDa}$. This coding strategy is identical to that of tospoviruses $(6,23)$. Furthermore, a serological relation was found between the $\mathrm{N}$ proteins of the melon virus and WSMV, and

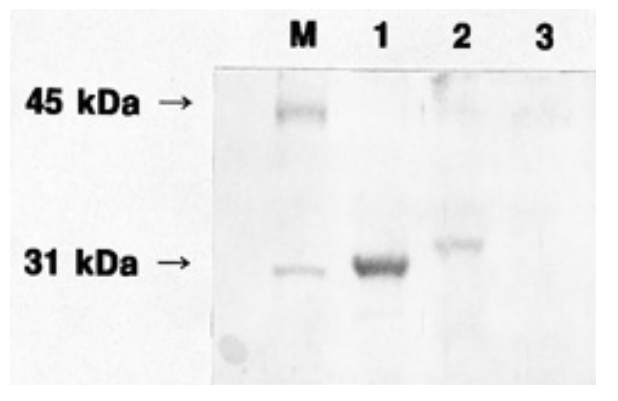

Fig. 6. Western blot analysis of the melon virus nucleocapsid $(\mathrm{N})$ protein after expression in Escherichia coli. Protein expression was induced for $3 \mathrm{~h}$ at $37^{\circ} \mathrm{C}$ by adding isopropyl- $\beta$-D-thiogalactopyranoside. After separation by $12 \%$ sodium dodecyl sulfate-polyacrylamide gel electrophoresis, proteins in extracts from transformed cells were transferred to nitrocellulose membranes. Polyclonal antiserum to a melon virus nucleocapsid preparation was used. Lane 1, nucleocapsid purified from infected cucumber; lane 2, extract from cells transformed with the expression vector containing the melon virus $\mathrm{N}$ gene; lane 3, extract from cells transformed with the expression vector that did not contain the melon virus $\mathrm{N}$ gene; Lane $\mathrm{M}$, biotinylated protein molecular weight markers (Bio-Rad Laboratories, Hercules, CA).

PBNV MSNTKQLTEKKIKELLAGGSADVEIETEDSTPGFSFKA-FYDTNKNLEITFTNCLNILKCRKQIFAACKSGKYVFCGKTIVATNTDVGPDDWT 92

WBNV MSTVKQLTDKKIKDLLAGGAADVEIETEDATPGFSFKS-FYDNNKDVEITFTTCLNILKCRKQIFTACKNGKYNFCGKNIVATTAQVGPDDWT 92

WSMV MSNVKQLTEKKIKELLAGGTADVEIETEDSTPGFSFKAFFYN-NKNIEITFTNCLNILKCRKQIFAACKSGKYNFCGKNIVATSVDVGPEDWT 92

Tosp MSTVAKLTKEKIQELLSGGKSEVEIETEESTEGFNFHSFFTDVRDEVKLYYNGITILKSRKQVYAACKSGMYKFCGKKIVASGDNVGPNDWT 93

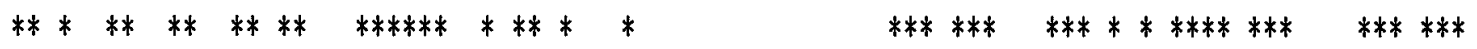

PBNV FKRTEAFIRTKMASMVEKSKNDAAKQEMYNKIMELPLVAYYGLNVPASFDTCALRMLCIGGPLPLLSSMTGLAPI IFPLAYYQNVKKEKLGI 185

WBNV FKRTEAFIRTKMVMVEKSTNENAKQEMYTKTMELPLVAAYGLNVPAYIDSCALRMLCIGGPLPLLSSVGGLAPVIFPLAYYQNVKKEKLGI 185

WSMV FKRTEAFIRTKIVSMVEKSKNEAARQEMYGKIMELPLVAYYGLNVPASYDSCALRMLCIGGPLPLLSSIRGLAPI IFPLAYYQNIKKEKLGI 185

Tosp FKRTEAVIRTLMISIAEKTENEEEKQLMMEKAMQLPLVAAYGLTVAKFDMTALRLMCIGGPLSLLASLHSLCPVVLPLAYFQNVKKEQLGI 186 $* * * * * * * * * \quad * \quad * * \quad * \quad * * * * * * * * * * * * * * * * * \quad * * * * * * * * * * * * * * * * * * \quad * * * * * * * * * * * *$

PBNV KNFSTYEQVCKVAKVLSASQIEFKNELEEMFKSAVKLLSESNPGTASSISLKKYDEQVKYMDKAFSASLSMDDYG-EHSKKK-SSKAGPSLEL 276

WBNV KNFSTYEQVCKVAKVLSASQIEFKGELDMFKSAVELLSKSNPGTASSISLKKYDDQVKYMDRVFNASLSMDDYG-EHS-KK-SSKASTSLEV 275

WSMV KNFSTYEQVCKVAKVLSASQVEFKDDLDVMFKQAVKILSESNPGTASSISLKKYEDQVKYMDRVFSANLSVDDYG-DHS-KK-SSKPSTSLEV 275

Tosp KNFSTYEQICKIARVMSASNMTFKKEFDELFKSCVKILADCKPGTTSGISLKIYNEQVQFMEQAFKSSLVDGMGESSSKSKASSSRSKSIEV 279

$* * * * * * * * * * * * * * * * * \quad * * * * * \quad * * * * * * * * * * * * * \quad * \quad * * * * \quad * * * * \quad * *$

Fig. 5. Multiple sequence alignment of nucleocapsid proteins from the melon virus and three tospoviruses in serogroup IV. Sequence data was obtained from Satyanarayana et al. (32) for Peanut bud necrosis virus (PBNV), Jain et al. (16) for Watermelon bud necrosis virus (WBNV), and Yeh et al. (36) for Watermelon silver mottle virus (WSMV). The alignment was done using GENETYX-MAC software. Perfectly conserved residues are indicated by an asterisk. Tosp $=$ sequence of the melon virus. 
sequence analysis revealed that the sequence identity between these $\mathrm{N}$ proteins was $58 \%$. Together, these results suggest that the melon virus belongs to the genus Tospovirus. However, the complete nucleotide sequence of the putative S RNA has not been determined; therefore, it is not clear whether an NSs protein is encoded at the $5^{\prime}$ end, whether an A-U-rich intergenic region separates the $\mathrm{N}$ and NSs genes, or whether inverted complementary repeats are present at the termini, as is the case for S RNAs of all reported tospoviruses.

The coding capacity of the melon virus $\mathrm{N}$ gene (279 amino acids) is larger than that of any tospovirus reported so far $(1,3,5$, $14,19,28,29,33)$. Comparisons of $\mathrm{N}$ protein amino acid sequences revealed that the melon virus was most closely related to three tospoviruses in serogroup IV, but identities with these three tospoviruses were only $\approx 60 \%$. It has been proposed that any tospovirus with an $\mathrm{N}$ protein sequence showing less than $90 \%$ identity with that of any other tospoviruses should be considered a distinct species (7). Therefore, we conclude that the melon virus isolate studied here is a distinct species in the genus Tospovirus for which we propose the name Melon yellow spot virus.

\section{ACKNOWLEDGMENTS}

We thank S. Tsuda (Ibaraki Plant Biotechnology Institute) and S. Hidaka (Tohoku National Agricultural Experiment Station) for their cooperation in direct RNA sequencing.

\section{LITERATURE CITED}

1. Cortes, I., Livieratos, I. C., Derks, A., Peters, D., and Kormelink, R. 1998. Molecular and serological characterization of iris yellow spot virus, a new and distinct tospovirus species. Phytopathology 88:1276-1282.

2. de Avila, A. C., de Haan, P., Kitajima, E. W., Kormelink, R., Resende, R. de O., Goldbach, R. W., and Peters, D. 1992. Characterization of a distinct isolate of tomato spotted wilt virus (TSWV) from Impatiens sp. in the Netherlands. J. Phytopathol. 134:133-151.

3. de Avila, A. C., de Haan, P., Kormelink, R., Resende, R. de O., Goldbach, R. W., and Peters, D. 1993. Classification of tospoviruses based on phylogeny of nucleoprotein gene sequences. J. Gen. Virol. 74:153-159.

4. de Avila, A., Pozzer, L., Bezerra, I., Kormelink, R., Prins, M., Peters, D., Nagata, T., Kitajima, E., and Resende, R. 1998. Diversity of tospoviruses in Brazil. Pages 32-34 in: Abstr. Int. Symp. Tospoviruses Thrips Floral Veg. Crops, Wageningen, Netherlands.

5. de Haan, P., Wagemakers, L., Peters, D., and Goldbach, R. 1990. The S RNA segment of tomato spotted wilt virus has an ambisense character. J. Gen. Virol. 71:1001-1007.

6. German, T. L., Ullman, D. E., and Moyer, J. W. 1992. Tospoviruses: Diagnosis, molecular biology, phylogeny, and vector relationships. Annu. Rev. Phytopathol. 30:315-348.

7. Goldbach, R., and Kuo, G. 1996. Introduction: Proceedings of the international symposium on tospoviruses and thrips of floral and vegetable crops. Acta Hortic. 431:21-26.

8. Hanada, K., Tsuda, S., Kameya-Iwaki, M., and Tochihara, H. 1993. Distinct properties of nucleocapsid of a watermelon isolate of tomato spotted wilt virus. Ann. Phytopathol. Soc. Jpn. 59:500-506.

9. Hibi, T., and Saito, Y. 1985. A dot immunobinding assay for the detection of tobacco mosaic virus in infected tissues. J. Gen. Virol. 66:1191-1194.

10. Hidaka, S., Hanada, K., Ishikawa, K., and Miura, K. 1988. Complete nucleotide sequence of two new satellite RNAs associated with cucumber mosaic virus. Virology 164:326-333.

11. Ie, T. S. 1971. Electron microscopy of developmental stages of tomato spotted wilt virus in plant cells. Virology 43:468-479.

12. Ie, T. S. 1982. A sap-transmissible, defective form of tomato spotted wilt virus. J. Gen. Virol. 59:387-391.

13. Iwaki, M., Honda, Y., Hanada, K., Tochihara, H., Yonaha, T., Hokama, K., and Yokoyama, T. 1984. Silver mottle disease of watermelon caused by tomato spotted wilt virus. Plant Dis. 68:1006-1008.

14. Jain, R. K., Pappu, H. R., Pappu, S. S., Krishna Reddy, M., and Vani, A. 1998. Watermelon bud necrosis tospovirus is a distinct virus species belonging to serogroup IV. Arch. Virol. 143:1637-1644.

15. Kato, K., Hanada, K., and Kameya-Iwaki, M. 1999. Transmissions mode, host range and electron microscopy of a pathogen causing a new disease of melon (Cucumis melo) in Japan. Ann. Phytopathol. Soc. Jpn. 65:624627.

16. Kitajima, E. W., de Avila, A. C., Resende, R. de O., Goldbach, R. W., and Peters, D. 1992. Comparative cytological and immunological labelling studies on different isolates of tomato spotted wilt virus. J. Submicrosc. Cytol. Pathol. 24:1-14.

17. Kobatake, H., Osaki, T., Yoshioka, A., and Inouye, T. 1976. Spotted wilt disease of tomatoes in Japan. Ann. Phytopathol. Soc. Jpn. 42:287-294. In Japanese.

18. Laemmli, U. K. 1970. Cleavage of structural proteins during the assembly of the head of bacteriophage T4. Nature (Lond.) 227:680-685.

19. Law, M. D., Speck, J., and Moyer, J. W. 1991. Nucleotide sequence of the $3^{\prime}$ non-coding region and $\mathrm{N}$ gene of the S RNA of a serologically distinct tospovirus. J. Gen. Virol. 72:2597-2601.

20. Lawson, R. H., Dinelt, M. M., and Hsu, H. T. 1996. The cytopathology of tospovirus-host-plant interactions. Proceedings of the international symposium on tospoviruses and thrips of floral and vegetable crops. Acta Hortic. 431:267-290.

21. Lawson, R. H., Dienlet, M. M., and Hsu, H. T. 1996. Ultrastructural comparisons of defective, partially defective, and nondefective isolates of impatiens necrotic spot virus. Phytopathology 86:650-661.

22. Milne, R. G. 1970. An electron microscope study of tomato spotted wilt virus in sections of infected cells and in negative stain preparations. J. Gen. Virol. 6:267-276.

23. Mumford, R. A., Barker, I., and Wood, K. R. 1996. The biology of the tospoviruses. Ann. Appl. Biol. 128:159-183.

24. Resende, R. de O., de Haan, P., de Avila, A. C., Kitajima, E. W., Kormelink, R., Goldbach, R., and Peters, D. 1991. Generation of envelope and defective interfering RNA mutants of tomato spotted wilt virus by mechanical passage. J. Gen. Virol. 72:2375-2383.

25. Sambrook, J., Fritsch, E. F., and Maniatis, T. 1989. Recovery of DNA from low-melting-temperature agarose gels. Pages 6.30-6.31 in: Molecular Cloning. N. Ford et al., eds. Cold Spring Harbor Laboratory Press, Cold Spring Harbor, NY.

26. Sambrook, J., Fritsch, E. F., and Maniatis, T. 1989. Electrophoresis of RNA through gels containing formaldehyde. Pages 7.43-7.45 in: Molecular Cloning. N. Ford et al., eds. Cold Spring Harbor Laboratory Press, Cold Spring Harbor, NY.

27. Sanger, F., Nicklen, S., and Coulson, A. R. 1977. DNA sequencing with chain-terminating inhibitors. Proc. Natl. Acad. Sci. USA 74:5463-5467.

28. Satyanarayana, T., Gowda, S., Lakshminarayana Reddy, K., Mitchell, S. E., Dawson, W. O., and Reddy, D. V. R. 1998. Peanut yellow spot virus is a member of serogroup V of tospovirus genus based on small (S) RNA sequence and organization. Arch. Virol. 143:353-364.

29. Satyanarayana, T., Mitchell, S. E., Reddy, D. V. R., Brown, S., Kresovich, S., Jarret, R., Naidu, R. A., and Demski, J. W. 1996. Peanut bud necrosis tospovirus S RNA: Complete nucleotide sequence, genome organization and homology to other tospoviruses. Arch. Virol. 141:85-98.

30. Satyanarayana, T., Mitchell, S. E., Reddy, D. V. R., Kresovich, S., Jarret, R., Naidu, R. A., Gowda, S., and Demski, J. W. 1996. The complete nucleotide sequence and genome organization of the M RNA segment of peanut bud necrosis tospovirus and comparison with other tospoviruses. J. Gen. Virol. 77:2347-2352.

31. Ullman, D. E., German, T. L., Sherwood, J. L., Westcot, D. M., and Cantone, F. A. 1993. Tospovirus replication in insect vector cells: Immunocytochemical evidence that the nonstructural protein encoded by the S RNA of tomato spotted wilt tospovirus is present in thrips vector cells. Phytopathology 83:456-463.

32. van Poelwijk, F., Prins, M., and Goldbach, R. 1997. Completion of the impatiens necrotic spot virus genome sequence and genetic comparison of the L proteins within the family Bunyaviridae. J. Gen. Virol. 78:543-546.

33. Yeh, S.-D., and Chang, T.-F. 1995. Nucleotide sequence of the $\mathrm{N}$ gene of watermelon silver mottle virus, a proposed new member of the genus Tospovirus. Phytopathology 85:58-64. 